\title{
Transforming Marawi's Transactions to Islamic Finance
}

\author{
Dr. Abdulcader M. Ayo and Dr. Minombao R. Mayo \\ Mindanao State University, \\ Marawi, Philippines
}

\begin{abstract}
This study aimed to find out the views of the different respondents regarding transactions in the aspects of banking, insurance and loans. The respondents of this study were bankers, employees, Ulama and professionals. To address this concern, the study was done through survey method by distributing questionnaire to 200 respondents. To determine the number of participants, purposive sampling technique was used in collecting the samples, and random sampling in selecting the number of respondents involved in the study. The major findings of the study showed that most of the respondents believed that by transforming transactions to Islamic finance, it will help in the prohibition of Riba (Usury) and bank-based interest free. Also, most of the respondents believed that Islamic finance will help them in their financial needs compared to conventional banks. Findings further denote on the need to strengthen Islamic finance in Marawi City. Thus, it is hereby recommended that Islamic finance should be implemented as it represents the true meaning of transactions in Islam, and it is a praiseworthy alternative for Muslims. Also, it is recommended on the existing Land bank and Philippine National Bank in Marawi City to open for a separate Islamic window wherein the terms for deposit and savings are in Islamic conducts. As for the Insurance and loans, it would be best for Muslims to have its own Islamic pawnshop and an Insurance company equivalent to Takaful which follows the concept and Shari'ah principles on Islamic finance. Additional recommendation is for Muslims to support the development of Islamic finance in Marawi City for economic growth and opportunities, and for global competitiveness. Moreover, an emphasis on the need for Ulama and those who are expert in this area are to raise awareness among others. The current situation of Marawi's residents because of the Siege is an indicator of the need to transform the place's transactions to Islamic ways. Finally, a room for improvement on the aspect of the knowledge on Islamic finance as it is required for Muslims to exercise what is right and due to his fellow Muslims.
\end{abstract}

Keywords: Transactions, Islamic Finance, Banking, Insurance, Loans.

\section{Introduction}

The principles of Islamic law stipulated in the Shari'ah emphasized the practice of Islamic finance in engaging financial and business transactions. In this recent times, Islamic Banking and Finance is recognize by both Muslims and non-Muslims to be useful and effective way in the development of the economy in the country.In Muslim countries, Islamic Banking and Finance is promoted including Philippines. This kind of banking and finance is stipulated in the Bangsamoro Organic Law which to be implemented in some selected provinces in Mindanao.

Abedifar, Ebrahim, Molyneux \& Tarazi (2015) emphasize that the efficiency, competition and risk features of Islamic banks is not different in the conventional banks. However, in terms of risk/return features in mutual funds Islamic funds perform better than conventional funds. This is due to some evidence that Islamic finance is less risky than conventional banking and finance. On the other hand, research showed that the greater percentage of Muslim population in the area is the determinant of the diffusion of Islamic Banks, but, its economic growth has no significant correlation to Islamic banking (Jhonson, 2013). 
Nawaz (2017) research findings revealed that awareness about Islamic Banking role and services is advantage for getting more clients particularly in the social and economic growth in Pakistan. They added that orientation is crucial in the determining the success and institutional role in the banking industry.

A study on customer perceptions towards the Islamic banking operations conducted by Toraman, Buğan and Ata (2015) revealed that prospect clients and participants perceptions about Islamic banking significantly varies, and accordingly evaluation of banking activities as alternative banking system should be well-understood by the customers. Similarly, Zainol, Shaari \& Ali (2008) on comparative analysis of bankers on Islamic banking stressed out that there are more positive perceptions among bankers in Islamic banks despite of their limited experience in Islamic banking. They added that availability of well-trained and skilled employees must be hired in the Islamic banking enterprise. Hence, they recommended that there should be regular seminars and workshops to be organized to expose the employees to innovations of Islamic banking to meet its objectives. Their findings is supported by the research findings of Umair, Khan \& Khan (2017) mentioning that Islamic banking is perceived positively by overall consumers in Pakistan. Their study also revealed that statistically religious level, knowledge and awareness on Islamic banking positively influence Islamic financing and services in Pakistan. Furthermore, cooperation is crucial in providing innovative products to the customers.

Rahman (2018) conducted a survey on the perceptions and attitudes of tertiary student towards Islamic banking in Bangladesh. Her findings disclosed that most of them are aware and in favor on Islamic banking system with Shariah compliant. Thus, it is an obligation of every Muslim to have his/her transactions in Halal manner corresponding to the need for awareness, knowledge and practice of Islamic Finance.

\section{Materials and Methods}

The descriptive method of investigation was used in this study to get both quantitative and qualitative data. Data were collected from the respondents includes the demographic profile, level of awareness and understanding on Islamic Banking and Finance, and their perspectives and suggested actions of transforming Marawi's Financial Transactions to Islamic Finance.

This study was conducted in Marawi City, the capital and only city in the province of Lanao del Sur which originally named as "Dansalan". Dansalan in Meranaw is a place where ships berth - a port of entry. Within the province of Lanao del Sur, there is a beautiful lake, known in a local dialect as "ranao" where an ethnic identity "Meranaw" is derived, which means "people of the lake". Marawi City was originally the capital of Lanao before it was divided into two provinces such the Province of Lanao del Sur and Lanaodel Norte.

The above described place, the Marawi was the setting of the study. People there have different professions which are categorized as professionals, employees, bankers, and Ulama. They are the respondents of this study to serve the main purpose of the researcher to further emphasize the need to transform Marawi's transaction to Islamic Finance.

The respondents included in this study were two-hundred (200), composed of professionals, employees, bankers, and Ulama that will help the researcher to arrive credible results of the study.

The primary data needed in the study was gathered utilizing the survey questionnaire. However, the study followed the ethnical practices in conducting research. After the validation of the research instruments, the researcher sends permission letters to the identified respondents who are professionals, employees, bankers, and Ulama. As soon as permission was granted, the research instrument particularly the questionnaire, was given to the respondents for them to complete in within a week. Such a time frame is set to allot a longer time to them anticipating their commitments or responsibilities to attend to.

After a week, the questionnaires were collected. The researcher proceeded to the analysis of data. The statistical tools applied to analyze the gathered data from the respondents through selfmade questionnaire were Simple Frequency and Percentage and Weighted Mean. It aimed to condense responses of the respondents into summary numbers through table presentation which 
was easily understood by the researcher. The data provided in tables were analyzed and interpreted to get the findings that served as a basis for conclusions and recommendations of this study.

\section{Results}

The findings depicted that for frequency and percentage distribution of the respondents according to their age, $23 \%$ of the respondents belong to the age bracket of $40-45$ years old as the highest, and the lowest percentage of respondents is $6 \%$ which is 25 up to 30 years old. Majorities, $64 \%$ of the respondents are males and $36 \%$ are female respondents. Majority, $69 \%$ of the respondents are college graduate, followed by $19 \%$ respondents under the category of high school graduate. Another $10 \%$ falls under Master's degree graduate category. And a minimal $2 \%$ of the respondents are Doctorate graduate. Majority, $57 \%$ of the respondents are government employees. $34 \%$ of the respondents are private employees while only $9 \%$ are unemployed. Majority, $56 \%$ of the respondents are receiving $\mathbf{P} 45,000$ above. $24 \%$ of the respondents are receiving $\mathbf{P} 40,000$ up to P $45,000.6 \%$ of the respondents are receiving $\mathrm{P} 35,000$ up to $\mathrm{P} 40,000.3 \%$ of the respondents are receiving $\mathrm{P} 30,000$ up to $\mathrm{\nexists} 35,000$, the same percentage also for respondents who are receiving an amount of $\mathrm{P} 20,000$ up to $\mathrm{P} 25,000$. $2 \%$ are receiving $\mathrm{P} 15,000$ up to $\mathrm{P} 20,000$, and $2 \%$ of the respondents are recipient of $\mathrm{P} 15,000$ or below.

On the first four (4) indicators appertaining to the level of awareness and understanding on Islamic Finance and its purpose in alleviating poverty, the following indicators show their responses with respective ranks, summations and means such as: Ranked $1^{\text {st }}$ with a summation of 75 and a 3.00 mean is statement indicator "Interest in any transactions related to Islamic finance will be eradicated" which follow that respondents agreed on this indicator. The same on the indicator Ranked $2^{\text {nd }}$ summation of 75 and a 3.00 mean is statement indicator "It provides social-awareness on giving Zakat" which likewise respondent demonstrate responsiveness on the cited indicator. On the last statement indicator Ranked $3^{\text {tdc }}$ Poverty will be lessened if there is an operation of Islamic finance" with a summation of 75 and a 3.00 mean likewise revealed utmost agreement of the respondents to the indicators.

On the other hand, the awareness of the respondents on Islamic Finance in terms of development, it is hereby discussed with the following indicators with respective rank, summation and mean such as: Ranked $1^{\text {st }}$ with a sum of 192 and 2.560 mean is statement indicator "It strengthens the Religion Islam" respondents strongly agreed on the statement given. The same on the indicator "Islamic Banking will be very valuable to all" ranked $2^{\text {nd }}$ with a sum of 187 and 2.493 mean fall on scale 2.34 to 3.00 which mean that respondents satisfaction on the statement given. On the last indicator ranked $3^{\text {rdcc }}$ Takaful and Pawnshop will be operated Islamically" with a sum of 171 and 2.280 mean fall on the scale 1.66 to 2.33 .

With respect to the next indicators regarding the perspective on how Islamic finance can contribute in the rehabilitation and reconstruction of the Marawi City after the Siege, respondents agreed on five (5) statement indicators such as the following with its respective rank: Ranked 1 is the statement indicator "With the absence of interest, people of Marawi can start a clean business and transaction", Ranked 2 is the statement indicator "Islamic finance will minimize gambling", Ranked 3 is the statement indicator "Islamic finance will be a way for economic development", Ranked 4 is the statement indicator "transaction will be easy as it is in Islamic conduct", and the Ranked 5 is the statement indicator "Speculation on the Halality of transaction will be gone".

In the enumerated indicators, all of the respondents agreed that indeed Islamic finance can help in the rehabilitation and reconstruction of Marawi City. The following statement indicators are arranged according to their ranks as for the perspectives of the respondents on the benefits that Islamic finance can help in the prohibition of Riba (Interest) and in promoting Bank operation to be interest free. The respondents strongly agreed on the following: Ranked 1 is the statement indicator "Debts will be paid with no interest which is on the benefit of the debtors", Ranked 2 is the statement indicator "Islamic finance will minimize gambling and other Unislamic conducts", Ranked 3 is the statement indicator "Islamic finance will permit a person to earn a fair and profitable way of living. Ranked 4 is the statement indicator "transaction will be easy as it is in Islamic conduct", and the Ranked 5 is the statement indicator "Speculation on the Halality of transaction will be gone". 
In the actions to be suggested to transform Marawi's Financial Transaction into Islamic Finance, majority, $85 \%$ of the respondents agreed on the following statement indicators: Ranked $1^{\text {st }}$ is statement indicator "There has to be a separate Islamic window in the Philippine National Bank and the Landbank of the Philippines". The same on the indicator Ranked $2^{\text {nd }}$ is statement indicator "There is Insurance on Takaful as an Islamic counterpart on conventional insurance". On the last statement indicator Ranked $3^{\text {rd }}$ is statement indicator "There is a need for an encouragement on the people of Marawi City to have Islamic Cooperative and Waqf."

\section{Discussion}

The study made used of descriptive research design of investigation utilizing a combination of qualitative and quantitative approached in the interpretation of data. Data gathering involved the use of self-made questionnaires. Marawi Siege is a remarkable incident to consider why most of the respondents, the Ulama, professionals, bankers and employees agreed on transforming Marawi's transactions to Islamic Finance.

The $4^{\text {th }}$ ASEAN International Conference on Islamic Finance pointed out that "Islamic banks are the financial intermediary that follows the shariah compliance not against the Qur'an and Hadith" which is what the Islamic City needs. Any transaction which is unlawful must be avoided (AICIF, 2016).

With the question provided for the respondents in terms of their level of awareness and understanding on Islamic finance as a method to alleviate poverty and the current state of Marawi City, the respondents find it as a way that with people's awareness and understanding of Islamic finance, this will help with the economic problem and growth of the place as Zakat will be comprehensible and due to people who are entitled to receive it which can also aid in the rehabilitation and reconstruction of Marawi City after the Siege. Comprehensive and appropriate framework and instruments to be used as guide and tools in regulation and supervision of Islamic Banking and Finance is vital. On the other hand, limited market coverage, lack of knowledge and understanding in Islamic Banking and Finance is a limiting factor in the implementation of Islamic Banking and Finance in the Philippines. As such, people should be well-informed about the concept of Islamic banking and finance.

Certainly, Islamic commerce differs from conventional commercial transaction in one aspect which is the paying or receiving of interest (riba). This kind of transaction is strictly prohibited in the Islamic commerce. This statement was mentioned by the respondents during interview. The respondents added that; Islam expressly forbids the giving or receiving of interest, which in the eyes of the Qur'an is tantamount to usury (riba).

Respondents' idea and knowledge in Islamic finance is that, zero interest is applied in all transactions. This unlawful transaction that has to be avoided comprises interest based transaction (Riba), this includes any transaction without faith to Allaah; Buying or selling a remuneration of an employee not yet encased; Buying or selling crops not yet harvested; and House and Life Insurance and the likes preconditioned with interest upon delay of monthly payment. Riba is 'Haram not only because of usury transactions, but it is an injustice way of helping the needy people since the borrower is obliged to pay the interest of the borrowed money. In this practice needy and poor people who borrowed money with interest will become poorer and could no longer pay the money borrowed but rather they will only pay the interest of it. As observed, poor and underdeveloped countries who borrowed money from rich and developed countries find it difficult to overcome their economic insufficiency because of the high interest rate in money lending. In the Islamic point of view, Chapter 2, Verse 278 in Qur'an clearly mentioned that asking interest or receiving interest is haram and not in accordance to ALLAH teaching.

In accordance with the findings of the study, it is clear that the level of awareness of Filipino Muslim in Islamic banking is not high considering that it not widely used in the country, but despite of it they show positive perceptions about Islamic Banking and Finance. This claim is supported by various researches. Essays, UK (2018) cited different research findings about perceptions in Islamic banking. Zainol, Shaari \& Ali (2008) mentioned that Islamic banking was not popular in 1970's. It is only widely exposed in the $21^{\text {st }}$ century. It is in the 21 st century that the inception of Islamic banking practices in different countries offers opportunities and threats for the banking sector in nonMuslim areas (Ahmad, Rehman \& Saif, 2010). In addition, Zaher and Hassan (2001) said that 
Islamic banking is a Shariah compliant. However, Hamid and Nordin (2001) emphasized that Shariah compliant is not the singly entity in determining success of Islamic banking. They said that, education, orientation, and knowledge dissemination about Islamic banking is very important considering that their research survey found out that $60 \%$ of the respondents is not knowledgeable and could not differentiate Islamic banking from conventional banking system. Hassan and Ahmed (2002) research findings also showed that their research respondents showed no interest in Islamic banking transactions because their knowledge and thinking was only the name of the bank is changed. They concluded that even employees knowledge has unclear or limited information on Islamic banking system that could lead to misunderstanding. Makiyan (2002) research also pointed out some limitations of the implementation of Islamic banking in Iran which is aside from limited knowledge and trainings; infrastructure problem was also experienced by banks employees.

On the other hand, Islamic banking and finance is foreseen to be a good approach in transforming Marawi City financial transaction considering Marawi City is the only Islamic City in Mindanao. During interviews, the respondents were asked about the transformation of Marawi conventional banking transaction into Islamic banking, they unanimously agreed the opening of Islamic Banking and Finance in the City and or opening an Islamic Window in the existing Philippine National Bank and Landbank of the Philippines, an Insurance which is equivalent to takaful, and the realization of Islamic cooperative and Waqf.

\section{Conclusion}

The advocacy in Islam is an economy based on equity, fair dealing and risk-sharing in both the financial and social-justice of the word. Islamic scholar based in Virginia Shaykh Yusuf DeLorenzo, said that the most interesting financial system is a system that has no interest. , No interest rate or prohibiting interest will keep everybody spend money according to his limit, that is in relation to Islamic finance.

Accordingly, based on the findings of the study, the following can be concluded: The major findings of the study showed that most of the respondents believed that by transforming transactions to Islamic finance, it will help in the prohibition of Riba (Usury) and bank-based interest free. Also, most of the respondents believed that Islamic finance will help them in their financial needs compared to conventional banks as people will have a social-awareness and socialresponsibility on giving Zakat. Findings further denote on the need to support Islamic finance in Marawi City to strengthen the religion Islam.

With the remarkable heartbreak happened to the Islamic City of Marawi, it would be best for its people to make all the transactions in the place in Islamic conducts. In this way also, the economic living of the people will prosper as Riba (interest) will be eliminated helping entrepreneurs by extending $0 \%$ interest loan. Thus, it is hereby recommended that Islamic finance should be implemented as it represents the true meaning of transactions in Islam, and it is a praiseworthy alternative for Muslims. Also, it is recommended on the existing Land bank and Philippine National Bank in Marawi City to open for a separate Islamic window wherein the terms for deposit and savings are in Islamic conducts. As for the Insurance and loans, it would be best for Muslims to have its own Islamic pawnshop and an Insurance company equivalent to Takaful which follows the concept and Shari'ah principles on Islamic finance. Additional recommendation is for Muslims to support the development of Islamic finance in Marawi City for economic growth and opportunities, and for global competitiveness.

Moreover, an emphasis on the need for Ulama and those who are expert in this area are to raise awareness among others. The current situation of Marawi's residents because of the Siege is an indicator of the need to transform the place's transactions to Islamic ways. Finally, a room for improvement on the aspect of the knowledge on Islamic finance as it is required for Muslims to exercise what is right and due to his fellow Muslims as stipulated in the Bangsamoro Organic Law in Muslim Mindanao.

\section{Acknowledgments}

Researchers would like to express their heartfelt appreciations to all those who in one way or another help them, especially the respondents for their cooperation that made the conduct of this study successful. 


\section{References}

Abedifar, P., Ebrahim, S. M., Molyneux, P., Tarazi, A. (2015). Islamic Banking and Finance: Recent Empirical Literature and Directions for Future Research. Journal of Economic Surveys, 29(4), 637-670.

Askari, H., Iqbal, Z., \& Mirakhor, A. (2009). New Issues in Islamic Finance and Economics: Progress and Challenges. Singapore: John Wiley \& Sons (Asia) Pte. Ltd.

Binder, S. and Ngai, J. (2009). Life Insurance in Asia Sustaining Growth in the Next Decade, Singapore: Wiley Finance.

UK Essays. (2018). Perception of Employees Working In Islamic Banks. Retrieved on November, 2018 from https://www.ukessays.com/dissertation/literature-review/banking/perception-of-employeesworking-in-islamic-banks.php?vref $=1$.

Harjito, D., \& Wiratama, M. (2017). The Balance Sheet Network Analysis for Measuring Systematic Risk of Islamic Commercial Banks in Indonesia. Journal of Islamic Finance, 6(1).

Johnson, K. (2013). The Role of Islamic Banking in Economic Growth. (Published Bachelors Thesis), Claremont McKenna College. Retrieved from https:// scholarship.claremont.edu/cgi/viewcontent.cgi?article=1618\&context $=$ cmc_theses.

Nawaz, H. N. (2017). Perceptions and acceptance of Islamic banking in Pakistan. International Sciences of Management Journal, 2(2), 1-14

Rahman, M. (2018). Exploring the Perceptions \& Attitudes of Tertiary Students' towards Islamic Banking in Bangladesh. (Published Internship Report), Dhaka: BRAC University.

Salem, R. A. (2013). Risk Management for Islamic Banks. Edinburgh: Edinburgh University Press.

Salman, S., Rashid, H., \& Hassan, R. (2016). Awareness and Knowledge of Insurance and Takaful in India: A Survey on Indian Insurance Policy Holders. Man In India, 97 (11), 127-140.

Toraman, C., Buğan, M. F., and Ata, H. A. (2015). A Study on Customer Perception towards the Islamic Banking Operations. Gaziantep University Journal of Social Sciences, 14(4), 761-779.

Riaz, U., Khan, M., \& Khan, N. (2017). An Islamic banking perspective on consumers' perception in Pakistan. Qualitative Research in Financial Markets, 9(4), 337-358.

Venardos, A. M. (2006). Islamic Banking and Finance in South-East Asia Its Development \& Future. Singapore: World Scientific Publishing Co. Pte. Ltd.

Vernados, A. M. (2010). Current Issues in Islamic Banking and Finance. Singapore: World Scientific Publishing Co. Pte. Ltd.

Zainol, Z., Shaari, R., \& Ali, H. M. (2008). A Comparative Analysis of Bankers' Perceptions on Islamic Banking. International Journal of Business and Management, 3(4), 157-168. 